\title{
The Problem of Commercial Application of Perovskite Solar Cells
}

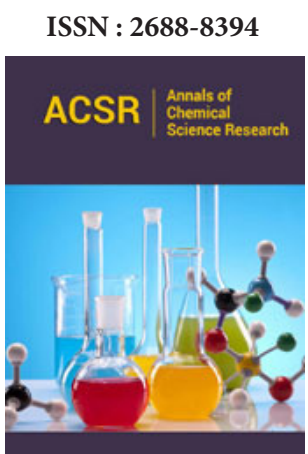

*Corresponding author: Shiqing $\mathrm{Bi}$, School of Chemistry and Chemical Engineering, China

Submission: 㳑 November 21, 2019

Published:

Volume 1 - Issue 5

How to cite this article: Xiaoyan $\mathrm{Xi}$, Shiqing Bi. The Problem of Commercial Application of Perovskite Solar Cells. Ann Chem Sci Res. 1(5).ACSR.000521.2019. DOI: 10.31031/ACSR.2019.01.000521

Copyright@ Shiqing Bi, This article is distributed under the terms of the Creative Commons Attribution 4.0 International License, which permits unrestricted use and redistribution provided that the original author and source are credited.

\author{
Xiaoyan Xi and Shiqing Bi* \\ School of Chemistry and Chemical Engineering, China
}

\begin{abstract}
Despite the power conversion efficiency (PCE) in organometal halide perovskite solar cells (PCSs) has achieved $23.7 \%$, the prospect commercial application is not optimistic. The stability and repeatability of conversion efficiency from small-area devices to large-area devices are the main reasons for preventing commercialization. Here, we will discuss these two aspects in detail.
\end{abstract}

Keywords: Perovskite solar cell; Commercial application; Stability; Repeatability; Large area

\section{Opinion}

In the last couple of years, solar cells based on organic-inorganic hybrid perovskite poly-crystallites have experienced a skyrocketing increase in the PCE, which enables their applications in generating the electricity with low-temperature process and earth-abundant materials [1-7]. The record-certified PCE of PSCs has recently risen to 23.7\% [8] for a smallarea device whose active area is well below that of standard commercial crystalline silicon solar cells. The first certified PCE of $16.63 \%$ for large area $\left(20.77 \mathrm{~cm}^{2}\right)$ is from Chen's group of Huazhong University of Science and Technology [9]. Compared with mature single crystal silicon solar cells (recorded at $26.7 \%$, area $79 \mathrm{~cm}^{2}$ ), there are still significant differences in large area and high efficiency. In addition, stability is also a problem that perovskite solar cells need to overcome for commercial applications. The perovskite solar cells exhibited acceptable stability in thermal stability tests at $80^{\circ} \mathrm{C}$ to $100^{\circ} \mathrm{C}$ for $2160 \mathrm{~h}$ comparing the life of a silicon solar cell with 25 years [10]. Therefore, the stability and repeatability of conversion efficiency from small-area devices to large-area devices are the main reasons for preventing commercialization.

For the stability, the lifetime of perovskite solar cells is affected by many factors and can be divided into two categories: external (environmental) and intrinsic. Good encapsulation can solve environmental factors, such as moisture and oxygen. The composition of the perovskite structure itself is an intrinsic factor. For example, the organic methylammonium cation $\left(\mathrm{MA}^{+}\right)$ easily absorbs water and causes decomposition of the perovskite. Many researchers have improved their stability by partially replacing or completely replacing $\mathrm{MA}^{+}$with inorganic cations $\left(\mathrm{Cs}^{+}, \mathrm{K}^{+}, \mathrm{Na}^{+}\right)$[11-13], and have achieved good results. The internal factors affecting the stability of the perovskite solar cells are still being studied, but it is clear that the interface between the perovskite and the contact layers has a great influence on the stability of the solar cells.

Another problem is that the PCE of devices cannot be repeated when a small-area device is expanded to a large area. Due to the large number of defects in large-area perovskite films, the PCE of large-area perovskite solar cells is far less than that of small-area devices in the laboratory. In recent years, researchers have improved the quality of large-area perovskite films through blade coating, CVD method, sequential desopition and screenprinting technology [14-18]. For example, In June 2014, Seo and co-workers for the first time demonstrated a solution-processing method for the fabrication of a $10 \mathrm{~cm} \times 10 \mathrm{~cm}$ (active area of $60 \mathrm{~cm}^{2}$ ) p-i-n perovskite solar module, which exhibited a PCE of 8.7\% [17]. Deng et al. [14] fabricated 1 -inch ${ }^{2}$ area perovskite films by using the modified doctor-blading method and got an exciting efficiency of $15.1 \%$ [13]. The PCE of large-area modules of perovskite solar cells has made great progress, but there is still no industrial production. 
In summary, perovskite solar cells as a promising candidate for the next generation of photovoltaic technologies have recently gained much attention both from the scientific and industrial community. However, even though the performance of PSCs exhibits a dramatic improvement, the difficulty on scaling-up becomes a bottleneck of industrialization. The efficiency from area enlargement and stability issues are urgent to be concerned and solved.

\section{References}

1. Kojima A, Teshima K, Shirai Y, Miyasaka T (2009) Organometal halide perovskites as visible-light sensitizers for photovoltaic cells. J Am Chem Soc 131(17): 6050-6051.

2. Im J H, Lee C R, Lee J W, Park S W, Park NG (2011) 6.5\% efficient perovskite quantum-dot-sensitized solar cell. Nanoscale 3(10): 4088-4093.

3. Lee MM, Teuscher J, Miyasaka T, Murakami TN, Snaith HJ (2012) Efficient hybrid solar cells based on meso-super structured organometal halide perovskites. Science 338(6107): 643-647.

4. Noh JH, Im SH, Heo JH, Mandal TN, Seok SI (2013) Chemical management for colorful, efficient and stable inorganic-organic hybrid nanostructured solar cells. Nano Letter 13(4) 1764-1769.

5. Lin Q, Armin A, Nagiri RCR, Burn PL, Meredith P (2014) Electro-optics of perovskite solar cell. Naure Photonics 9: 106-112.

6. Bi DQ Tress W, Dar MI, Gao P, Luo JS, et al. (2016) Efficient luminescent solar cell based on tailored mix-cation perovskites. Science Advance 2(1): e1501170.

7. Yang WS, Park BW, Jung EH, Jeon NJ, Kim YC, et al. (2017) Iodide management in formamidinium-lead-halide-based perovskite layers for efficient solar cells. Science 356(6345): 1376-1379.

8. Hanul M, Maensuk K, Seung-Un L, Hyeonwoo K, Gwisu K, et al. (2019) Efficient, stable solar cells by using inherent bandgap of $\alpha$-phase formamidinium lead iodide. Science 366(6466): 749-753.
9. http://www.opticsjournal.net/Mobile/PostDetails/ PT180411000098y5A8D?code=3

10. Hu Y, Si S, Mei A, Rong Y, Liu H, et al. (2017) Stable large-area $(10 \times 10 \mathrm{~cm} 2)$ printable mesoscopic perovskite module exceeding $10 \%$ efficiency. Solar RRL 1(2): 1600019.

11. McMeekin DP, Sadoughi G, Rehman W, Eperon GE, Saliba M, et al. (2016) A mixed-cation lead mixed-halide perovskite absorber for tandem solar cells. Science 351(6269): 151-155.

12. Boopathi KM, Mohan R, Huang TY, Budiawan W, Yin ML, et al. (2016) Synergistic improvements in stability and performance of lead iodide perovskite solar cells incorporating salt additives. Journal of Materials Chemistry A 4(5): 1591-1597.

13. Saliba M, Matsui T, Domanski K, Seo J Y, Ummadisingu A, et al. (2016) Incorporation of rubidium cations into perovskite solar cells improves photovoltaic performance. Science 354(6309): 206-209.

14. Deng YH, Peng E, Shao YC, Xiao ZG, Dong QF, et al. (2015) Scalable fabrication of efficient organo-lead trihalide perovskite solar cells with doctor-bladed active layer. Energy Environmental Science 8(5): 15441550.

15. Jiang Y, Leyden M R, Qiu L, Wang S, Ono LK, et al. (2018) Combination of hybrid CVD and cation exchange for upscaling Cs-substituted mixed cation perovskite solar cells with high efficiency and stability. Advanced Function Materials 28(1): 1703835.

16. Chang CY, Huang WK, Chang YC, Lee KT, Chen CT (2016) A solutionprocessed $\mathrm{n}$-doped fullerene cathode interfacial layer for efficient and stable large-area perovskite solar cell. Journal of Materials Chemistry A 4(2): 640-648.

17. Priyadarshi A, Haur LJ, Murray P, Fu DC, Kulkarni S, et al. (2016) A large area $\left(70 \mathrm{~cm}^{2}\right)$ monolithic perovskite solar module with a high efficiency and stability. Energy Environmental Science 9(12): 3687-3692.

18. Seo J, Park S, Kim YC, Jeon NJ, Noh JH, et al. (2014) Benefits of very thin PCBM and LiF layers for solution processed p-i-n perovskite solar cells. Energy Environmental Science 7(8): 2642-2646. 